\title{
sIgA and Lisozim as Biomarker of Early Childhood Caries Risk
}

\author{
Essie Octiara \\ Doctoral Student \\ Faculty of Dentistry, Universitas Sumatera Utara \\ Medan, Indonesia \\ eoctiara@gmail.com \\ Yahwardiah Siregar \\ Department of Biochemistry \\ Faculty of Medicine, Universitas Sumatera Utara \\ Medan, Indonesia
}

\author{
Heriandi Sutadi \\ Department of Pediatric Dentistry \\ Faculty of Dentistry, Universitas Indonesia \\ Jakarta, Indonesia
}

\author{
Ameta Primasari \\ Department of Oral Biology \\ Faculty of Dentistry, Universitas Sumatera Utara \\ Medan, Indonesia
}

\begin{abstract}
Caries in children under 6 years old (Early Childhood Caries) is still a major oral health problems in many countries. The high prevalence of ECC should be prevented immediately based on the cause of caries. Saliva is one of the factors that play role in dental caries process, also play a role as caries prevention. This article describes the relationship between SIgA and salivary lysozyme to the incidence of ECC and the development of that protein as one of the caries biomarkers. Several studies reported that sIgA in caries-free children had higher concentrations than in ECC children. Lysozyme concentrations in unstimulated saliva are also significantly higher in the caries-free group compared with the ECC group. Determination of lysozyme and SIgA level in saliva may be helpful in diagnosing caries diseases and infections. It is concluded that the development of $\operatorname{SIgA}$ and salivary lysozyme can be used as one of the biomarkers for dental caries detection, risk assessment, diagnosis, prognosis and disease monitoring, and evaluation in ECC.
\end{abstract}

\section{Keyword-ECC, sIgA, salivary lysozyme, biomarker}

\section{INTRODUCTION}

Dental caries is still a major oral health problem in many countries including Indonesia. The unique caries lesions in infants, toddlers and preschoolers children are called Early Childhood Caries (ECC). The definition of ECC according to the American Academy of Pediatric Dentistry (AAPD) is the presence of carious lesions on the surface of deciduous teeth (cavity or not cavity), teeth lost by caries or restored teeth in children under 6 years old [1].

ECC epidemiological data from various countries shows varying numbers. In America, ECC incidence in 1 years old children has high prevalence which is $21 \%$ and increases in preschoolers age 5 years old by $75 \%[1,2]$. Study in India found that the prevalence of ECC varied by $27.5 \%$ [3] to $56.6 \%$ [4], while in Northern Thailand, it has higher prevalence which is $68.5 \%$ [5].

National data in 2007 and 2013 found that there was an increased in the caries prevalence in Indonesian children, it was reported that caries prevalence in children age 1-4 years old was 6.9\% [6], and increased by $3.5 \%$ to $10.4 \%$ [7]. Prevalence of ECC in children 3 years old and under in Surabaya and Medan was higher than the national data in Surabaya that reported $30.8 \%$ [8], while in Medan it was found higher by $57.7 \%$ [9].

The high prevalence of ECC in various countries must be prevent immediately based on the caries etiology. Caries occurs not because of one event but due to a series of processes over several periods, therefore caries is expressed as a multifactorial disease. There are three main factors that play role in caries disease which are host factors (teeth and saliva), agents (microorganisms) and substrates or diet and added with time factor. Caries will occur when each factor is mutually supportive [10].

Saliva is one of the factor that play role in dental caries process, also play a role as caries prevention [11]. Therefore, it is possible that saliva is used as a biomarker to assess a person's caries risk. Biomarkers serve to detect, risk assessment, diagnosis, prognosis and disease monitoring and health evaluation [12,13]. Biomarkers can be antibodies, microbes, DNA, RNA, lipids, metabolites and proteins. The change in concentration, structure, function, or action in analyte can be attributed to the onset, developmental regression of a particular disorder or the outcome of how the body responds [14]. Biomarkers are assessed through quantitative tests to determine specificity, sensitivity and reproducibility [13].

Increased use of saliva as a non-invasive diagnostic tool has been developed recently. Non-invasive methods will avoid patient's discomfort or fear in detecting the disease, because in sampling does not cause any pain. Besides economical, saliva is easily collected, delivered, and stored so that there is a decrease in overall costs for patients and healthcare providers [15].

Saliva proteins that can be used as dental caries biomarkers which serve as immune and nonimmune antimicrobial factors [16]. The main salivary immune factor is secretory $\operatorname{IgA}(\operatorname{Ig} \mathrm{A})$ [17], while non-immune factors in saliva include lysozyme, lactoferrine, salivary peroxidase, aglutinin, histatine, cystatine, secretory 
leucocyte proteinase inhibitor (SLPI), defensine-2, chromogranine A, cathelicidine, mucine, and prolin-rich glycoproteins [18]. Lysozyme is one of innate immune saliva and body's first defense and prominent in the oral cavity $[18,19]$.

Salivary immunoglobulin is formed due to antigen microorganisms in the oral cavity. The sIgA antimicroorganism interacts with antibody bonds on specific antigens in the bacterial cell wall resulting in bacterialleukocyte agglutination [20]. Research in children age 48 years found that the caries-free group had the highest total SIgA compared to control group with caries experience 1-5 teeth and 6-10 tooth [21].

The literature report shows that the determination of lysozyme levels in body fluids may be helpful in diagnosing several diseases such as atherosclerotic cardiovascular [22] and infections such as periodontal disease [23] as well as micro vascular trauma in smokers' lungs [24]. Lysozyme also can be used as an important marker for the diagnosis and development of dental caries. Study found that there was an association between lysozyme value and the number of S. mutans and lactobacillus [25]. Other studies reported that lysozyme concentration in unstimulated saliva was significantly higher in the caries-free group compared with ECC group [26].

The purpose of this article is to present the relationship between sIgA and salivary lysozyme with the incidence of ECC and the development of sIgA and saliva lysozyme as one of the biomarkers for detecting, risk assessment, diagnosis, prognosis and disease monitoring and evaluation of early childhood caries (ECC).

\section{LITERATURE REVIEW}

\section{A. Secretory immunoglobulin $a$ and the relationship} with ECC risk

sIgA is synthesized by B lymphocyte cells located around the secretory epithelium. Once secreted in the interstitial fluid, sIgA it is taken by acinar cells and salivary gland duct cells and then secreted into saliva [18]. The structure of $\operatorname{sIgA}$ is dimer [27], because two molecules of $\operatorname{IgA}$ (weight $300 \mathrm{kDa}$ ) are bonded into one complex by $\mathrm{J}$ chain binding protein (Joining Piece, weight $15 \mathrm{kDa}$ ). In addition, this complex has a protein in the form of a secretory component (secretory component, weight $70 \mathrm{kDa}$ ) that serves to stabilize the molecule and reduce susceptibility to proteolytic enzymes [28].

Salivary immunoglobulin is formed due to an antigen microorganisms in the oral cavity. The $\operatorname{sIgA}$ anti-microorganisms are able to interact by antibody bonds on specific antigens in the bacterial cell wall resulting in bacterial agglutination. Bacterial agglutination causes bacteria cannot make colonies again in the oral cavity and the results will be transported to the stomach. In addition, microorganisms that are covered by $\operatorname{sg} \mathrm{A}$ are more easily phagocytosed by leukocytes [20,29]. Another mechanism of $\operatorname{sIgA}$ protection against oral microorganisms is that the $\operatorname{sIgA}$ anti-microorganisms will mask the adhesion of microorganisms or antigen molecular receptors so that they cannot attach to salivary aglutinin glycoprotein receptors (SAGs) on tooth surfaces [30]. The sIgA is also capable to neutralize extracellular enzymes produced by microorganisms [31]. This can cause the microorganisms not attached to the tooth surface [29].

IgA has not yet been discovered in baby after birth. It is secreted by a month-old infant, that subsequently undergo maturation process from mucosal immune response that occurs at the end of one years old [28]. In child's saliva, the sIgA concentration contains half of the sIgA concentration in adult and this value will remain low until the end of the first year or even past that age [20]. Khan et.al [29] showed that age affect changes in sIgA concentration. The mean of $\operatorname{sIgA}$ was higher in individuals age $11-20$ years old $(7.47 \pm 1.48 \mathrm{mg} / \mathrm{dl})$ than children age $1-10$ years old $(5.20 \pm 0.94 \mathrm{mg} / \mathrm{dl})$, but the mean of sIgA will decrease at individuals age 61-70 years old [17].

Saliva' immune response to streptococci mutans showed an individual characteristics in childhood. Each child responds differently to streptococci mutans infection, a condition that results from an extension of infection (antigen dose) or age at the time of infection (maturation of the immune response) [32].

Antibodies to S. mutans can be detected in saliva, but their relationship with immunity to caries is still a contradiction. Research in children age 4-8 years old found that the caries-free group had highest total of $\operatorname{sIgA}$ compared to groups of children with caries experience 15 teeth and 6-10 tooth [21]. Same results were also reported by Pal et al. [33], that the highest total $\operatorname{sigA}$ in caries-free group were $213.67 \pm 28.17 \mu \mathrm{g} / \mathrm{ml}$, followed with moderate caries children (1-4 teeth) $189.13 \pm 26,74$ $\mu \mathrm{g} / \mathrm{ml}$ and lowest in children with high caries (5-15 teeth) which was $144.13 \pm 20.85 \mu \mathrm{g} / \mathrm{ml}$.

Different results reported that there was no difference in total $\operatorname{sigA}$ concentrations in caries-free children with children having caries experience $\geq 5$ [27]. Bagherian \& Asadikaram [34] reported the opposite results that the highest total $\operatorname{sIgA}$ concentration was owned by ECC children $(196.14 \pm 100.07 \mathrm{mg} / \mathrm{dl})$ than in caries-free children $(148.45 \pm 81.26 \mathrm{mg} / \mathrm{dl}$; $\mathrm{p}=0.015)$.

From several studies, it can be concluded that there was a relationship between $\operatorname{sig} \mathrm{A}$ concentration and caries incidence [21, 33, 34], therefore $\operatorname{sIgA}$ concentrations could be developed as an ECC risk assessment biomarker.

\section{B. Salivary lysoyzme relationship with ECC}

The lysozyme (or muramidase) (EC 3.2.1.17) is a small protein $(14.6 \mathrm{kDa})$ with isoelectric points $(\mathrm{pI}) 10$ 11 and is cationic [35]. Lysozyme can be divided into several types based on the sequence of similarities and its three dimensional structure: 1). Type c (chicken-type lysozyme); 2). Type g (goose-type lysozyme); 3). Type i (invertebrate-type); 4). T4 phage lysozyme (phage-type); 5). Bacterial lysozyme; 6). Plants lysozyme. Human lysozyme is included in type c [36]. 
Human lysozyme has 130 single polypeptide chain amino acids [36]. There are four disulfide bridges that serve to stabilize the molecule in a compact ellipsoidal form [37]. Human lysozyme genes are the LYZ gene, with the length of the gene structure is $5856 \mathrm{bp}$. The lysozyme gene is a small gene with 4 exons structure and 3 sequence interventions that is very similar to the chicken lysozyme genes. The main differences between human and chicken lysozyme genes is in the size of introns and 3 non-coding regions [38].

Human lysozyme is produced by monocytes, neutrophils, Paneth cells and salivary glands [39,40]. Lysozyme is a non-specific immune cell response, and lies between blood system cells especially leukocytes [37].

The lysozyme enzyme has a small concentration in the salivary glands, but has significant biological activity [18]. Lysozyme concentration in saliva is reported vary from 2 to $60 \mu \mathrm{g} / \mathrm{ml}$. The fluid in dental plaque is reported to contain up to 15 times the amount of saliva lysozyme [41]. Lysozyme concentration in breast milk is about $100 \mu \mathrm{g} / \mathrm{ml}$, and this concentration will increase at the end of lactation [40].

Lysozyme acts as an antibacterial, antiviral, and antitumor and immune modulator activity [42]. Lysozyme activity as antimicrobial relates to its ability in lytic action in bacteria [43] by hydrolyzing $\beta$ (1-4) bonds between $\mathrm{N}$-acetylmuramic acid and $\mathrm{N}$ acetylglucosamine in peptidoglycan layer of bacterial cell wall [26]. Glycosidic bond hydrolysis results will cause the occurrence of small pores inside bacterial cell wall so that bacteria will die. Lysozyme primarily hydrolyze cell walls of Gram-positive microorganisms, such as S. mutans [44]. Gram-negative bacteria are generally much less sensitive to lysozyme because the murein content in the cell wall is only $10 \%$, whereas in Gram-positive it is 50\% [18].

Lysozyme as a strong cationic protein, can also mediate bacterial aggregation and inhibit bacterial attachment and also activate bacterial autolysin by destroying bacterial cell walls [26,43]. The lysozyme activity will survive when the enzyme is absorbed in the pellicle [45]. The absorption of cationic molecules against bacterial walls is highly dependent on $\mathrm{pH}$ and ionic strength [43].

The concentration of saliva lysozyme in humans varies with age. A longitudinal study by Hyypp et al. [46] found that the concentrations of lysozyme did not differ between pre-dente groups (age 2-6 months, mean age 4.3 months) with dentate phase group (12-19 months, mean age 12, 7 months). Lysozyme concentrations in these two groups of children were lower than in the adult group (age 21-31 years, mean age 23.3 years).

Researcher de Andrade FB et al. [19] found that bactericidal and bacteriostatic effects of lysozyme against S. mutans were $68.5 \mathrm{mg} / \mathrm{mL}$ (MBC concentrations) and $58.7 \mathrm{mg} / \mathrm{mL}$. Other studies found that concentrations of lysozyme required to inhibit biofilm formation is $50-200 \mu \mathrm{g} / \mathrm{ml}$ [47].
Development of salivary lysozyme as one of ECC risk assessment biomarkers can be done, Mass et al. [25] had found a link between lysozyme value and the number of S. mutans. Other investigators reported that the concentration of unstimulated salivary lysozymes in ECC children was higher than in caries-free children [48]. Similarly, Letsirivorakul et.al. [49] obtained similar results, unstimulated saliva sample taken from 32 caries-free children and 32 children with caries showed the concentration and lysozyme activity in children with caries were higher than in caries-free children $(\mathrm{p}=$ 0.008). Different results reported by Felizardo et.al [50] that found lysozyme unrelated to the caries experience. Hao \& Lin's study [51] also states the same, there were no differences in lysozyme concentrations between caries groups and children have caries $(\mathrm{dmft}>5)$.

In a study of 21 children age 36-71 months cariesfree compared to 21 children with ECC, the concentration of lysozyme in unstimulated saliva was significantly higher in the caries-free group compared with the ECC group $(p=0.04)$. The study also evaluated 3 months later, after all carious teeth performed dental treatment. There was no difference in lysozyme value between baseline values before dental treatment compared with after dental treatment, although substantially higher lysozyme value was in after dental treatment than baseline [26]. Bhalla's study [52] also obtained a DMF-T index decreasing as the concentration of lysozyme increased.

\section{DISCUSSION}

The study of total sIgA concentrations associated with caries occurrences has been widely reported, and more recent research that specify $\operatorname{sIgA}$ on S. mutans has been widely developed. Research has reported a tendency of higher intensity and a more complex pattern of serotype c anti-S. mutans responses in low caries individuals compared with caries-free individuals [53]. Other literature states that higher serotype $\mathrm{c}$ anti-S. mutans response in caries-free individuals than individuals with active caries [20]. SIgA response to low effect of anti-serotype c S. mutans in caries development is not very clear, it may be due to a wide range of specificities sIgA against the antigen virulence of microorganisms [54].

$\mathrm{S}$. mutans serotype $\mathrm{c}$ is reported to be most commonly about found serotype which is $70-80 \%$, followed by serotypes e, f and k [55]. In Finnish children samples found $75-90 \% \mathrm{~S}$ mutans with serotype c, 10$20 \%$ serotype e, and few serotypes $\mathrm{f}$ [56]. In various studies it was found that serotype $\mathrm{f}$ is rare in individuals $[57,58,59]$. However, research in Jakarta in children age 3-5 years old, found that serotype $\mathrm{f}$ is more dominant bacteria that is equal to $91 \%$, followed by serotype c $79 \%$ and serotype e of $29 \%$ [60]. The study reported that children with dental caries had a higher anti-S. mutans serotype $f$ than a caries-free child, although statistically this difference was not significant [61]. Serotype f had possibility to plays a role in the incidence of caries at an early childhood. 
Lysozyme antibacterial effect depends on the lysozyme concentration and activity in saliva. Results reported that many studies try to relate lysozyme concentrations with ECC events, but lysozyme activity level may be more relevant to explain the defensive role of the protein. Research that distinguishes between active and inactive lysozymes in saliva will yield better results than simply describe concentrations [62].

The type of lysozyme used in the biomolecular examination may also affect a study result. Iacono et.al [63] found that human lysozyme 3-4 times more reactive than hen egg white lysozyme (HEWL). HEWL is very similar to human lysozyme and has 129 amino acids (14.3 kDa) [36]. HEWL is not expensive and it has good correlation to human lysozyme, therefore HEWL is often used in research as a substitute for human lysozyme. This is likely to lead some researchers to report that most microorganisms are not susceptible to lysozyme, but other studies suggest that lysozyme is effective against streptococci [63].

Study reported that the most susceptible HWEL inhibition of $\mathrm{S}$. mutans serotype $\mathrm{b}$ was at concentrations of $25 \mu \mathrm{g} / \mathrm{ml}$, whereas serotype c was intermediate, serotype $\mathrm{e}$ and $\mathrm{f}$ were the most resistant one. Of all serotypes, serotype $b$ has a negative potential and highest surface antigen, therefore cationic lysozyme molecule can bind to these microorganisms and can penetrate the cell wall to reach the substrate. The most dominant antigenic determinants for serotype e are fllinked glucose-glucose dimer and serotype f terminal a1,6-diglucose. Both disaccharide terminals may be suitable on the lysozyme active site and this prevents penetration of the enzyme through the bacterial cell wall. In $\mathrm{S}$. mutans extract study, serotype $\mathrm{f}$ is very effective in blocking the inhibition of lysozyme, but this extract not only consists of specific types of polysacchide, other cell components may be involved in this inhibition such as nucleoprotein, lipoteikoic acid and glycolipid membrane [63].

From several reports above, there was an inconsistent result of protective mechanism in salivary antimicrobial proteins with caries. This may be due to the antimicrobial agent depending on the individual salivary flow rate, the degree of gingival inflammation associated with gingival sulcus exudates and the release of antimicrobial proteins in whole saliva, caries status, total saliva $\mathrm{SIgA}$ and anti-Streptococcus mutans specific IgA varies with time of infection [17], other nonimmune antimicrobial agents also play a role, large intra and inter-individual variations; and also the age of the subject [64].

In addition, varied results between studies may also be due to inconsistency of study design, saliva collection methods and saliva analysis methods found in various studies. Many clinical studies investigate only one protein at a time (cross-sectional design), therefore it is necessary to consider examining several saliva proteins as an immune system element and evaluating protein concentrations longitudinally. Research with this design will be able to clarify the interactions between salivary proteins and can illustrate how salivary proteins may vary among populations [26].

Future research on development of salivary protein biomarkers must takes into account about factors that affect a person's salivary protein $[17,64]$, so that the research obtained is more valid. Besides, longitudinal study design is suggested, as it may explain the role of antibacterial saliva in ECC. It is hoped that there will be innovative development and research that can illustrate caries prediction and control (ECC), so that future care of dental caries will be based on three approaches: early detection, effective care and prevention.

As conclusion, $\operatorname{sIgA}$ and salivary lysozyme have an association to ECC events, and further studies is needed to developed $\operatorname{sIgA}$ and saliva lysozyme as one of the biomarkers for detecting, risk assessment, diagnosis, prognosis and disease monitoring and evaluation of dental caries in early childhood (ECC).

\section{REFERENCES}

[1] American Academy of Pediatric Dentistry (AAPD), "Policy on early childhood caries (ECC): Classifications, consequences, and preventive strategies," Refer. Man., vol. 37, pp. 50-52, 2014.

[2] K.R. Phipps, T.L. Ricks, M.C. Manz, P. Blahut, "Prevalence and severity of dental caries among American Indian and Alaska native preschool children, “ J. Public. Health Dent., vol. 72, pp. 208-215, Summer 2012.

[3] P. Prakash, P. Subramaniam, B.H. Durgesh, S. Konde," Prevalence of early childhood caries and associated risk factors in preschool children of urban Bangalore, India: A crosssectional study," Eur. J. Dent., vol. 6, pp. 141-152, April 2012.

[4] D. Agarwal, S. Sunitha, Cvk. Reddy, P. Machale, "Early childhood caries prevalence, severity and pattern in 3-6 year old preschool children of Mysore City, Karnataka," Pesq. Bras. Odontoped. Clin. Integr., vol.12, pp. 561-565, December 2012.

[5] K. Peltzer, A. Mongkolchati, "Severe early childhood caries and social determinants in three-year-old children from Northern Thailand: a birth cohort study," B.M.C. Oral Health, vol.15, pp. 108, September 2015.

[6] Badan Penelitian dan Pengembangan Kesehatan Kementrian Kesehatan RI. (2014, October 19) Riset kesehatan dasar 2007. Available: http://litbang.depkes.go.id.

[7] Badan Penelitian dan Pengembangan Kesehatan Kementrian Kesehatan RI (2014, October 19) Riset kesehatan dasar 2013. Available: http://litbang.depkes.go.id.

[8] R.W. Sutjipto, Herawati, S. Kuntari, "Prevalensi early childhood caries dan severe early childhood caries pada anak prasekolah di Gunung Anyar Surabaya," M. Kedokt. Gigi, vol. 47, pp. 186-189, December 2014.

[9] E. Octiara, E.A. Tamba, "Hubungan ekonomi keluarga dan pendidikan ibu dengan early childhood caries (ECC) anak usia 12-36 bulan di Kecamatan Medan Denai,” Dentika Dent. J., vol. 17, pp. 79, July 2012.

[10] O. Fejerskov, B. Nyvad, E. Kidd, Dental caries, the disease and its clinical management, $3^{\text {rd }}$ ed., Iowa: Wiley Blackwell, 2003 , pp. 100-104.

[11] D. Jayaraj, S. Ganesan, "Salivary $\mathrm{pH}$ and buffering capacity as risk markers for early childhood caries: A clinical study", J. C.P.D, vol.8, pp. 167-171, September-December 2015.

[12] S. Kurian, Y. Grigoryev, S. Head, D. Campbell, T. Mondala, D.R.Salomon, "Applying genomics to organ transplantation medicine in both discovery and validation of biomarkers," Int. Immunopharmacol., vol. 7, pp. 1948-1960, December 2007.

[13] S. Bonassi, M. Neri, R. Puntoni, "Validation of biomarkers as early predictors of disease," Mutat Res., vol. 480-481, pp. 349358, September 2001.

[14] P.D. Wagner, M.Verma, S. Srivastava, "Challenges for biomarkers in cancer detection," Ann. N. Y. Acad. Sci., vol. 1022, pp.9-16, June 2004. 
[15] J.M. Yoshizawa, C.A. Schafer, J.J Schafer, J.J. Farrell, B.J. Paster, D.T.W. Wong, "Salivary biomarkers: Toward future clinical and diagnostic utilities," Clin. Microbiol., vol. 26, pp. 781-91, October 2013.

[16] E. Ranadheer, U.A. Nayak, N.V. Reddy, V.A. Rao, "The relationship between salivary IgA levels and dental caries in children," J. Indian Soc. Pedod. Prev. Dent., vol. 29, pp. 106112, September 2011.

[17] A. Jafarzadeh, M. Sadeghi, G.A Karam, R. Vazirinejad, "Salivary IgA and IgE levels in healthy subjects: Relation to age and gender," Braz. Oral Res., vol. 24, pp. 21-27, JanuaryMarch 2010.

[18] A.V.N. Amerongen, J.G.M. Bolscher, E.C.I. Veerman, "Salivary protein: protective and diagnostic value in cariology ?" Caries Res., vol. 38, pp. 247-253, May-June 2004.

[19] F.B. de Andrade, J.C. de Oliveira, M.T. Yoshie, B.M. Guimarães, R.B. Gonçalves, W.D. Schwarcz, "Antimicrobial activity and synergism of lactoferrin and lysozyme against cariogenic microorganisms," Braz. Dent. J., vol. 25, pp. 165169, April 2014

[20] A. Cvetkovic, M. Ivanovic, "The role of Streptococcus mutans group and salivary immunoglobulins in etiology of early childhood caries," J. Serbian Dent., vol. 53, pp. 113-123, 2006.

[21] J. Chawda, N. Chaduvula, H. Patel, S. Jain, A. Lala, "Salivary sIgA and dental caries activity," Indian Pediatr., vol. 48, pp. 719-721, September 2011.

[22] V.B. Abdul-Salam, P. Ramrakha, U. Krishnan, D.R. Owen, J. Shalhoub, A.H. Davies, et al.," Identification and assessment of plasma lysozyme as a putative biomarker of atherosclerosis," Arterioscler. Thromb. Vasc. Biol., vol. 30, pp. 1027-1033, May 2010.

[23] S. Hani, H.S. AlMoharib, A. AlMubarak, R. AlRowis, A. Geevarghese, R.S. Preethanath, et al., "Oral fluid based biomarkers in periodontal disease: Part 1 saliva," J. I. O. H., vol. 6, pp. 95-103, July-August 2014.

[24] B. Schmekel, P. Blomstrand, P. Venge, "Serum lysozyme-a surrogate marker a pulmonary microvascular injury in smokers?" Clin. Physiol. Imag., vol. 33, pp. 307-312, July 2013.

[25] E. Mass, N. Gadoth, D. Harell, A. Wolff, "Can salivary composition and high flow rate explain the low caries rate in children with familial dysautonomia?" Pediatr. Dent., vol.24, pp. 581-586, November- December 2002.

[26] M. Moslemi, M. Sattari, F. Kooshki, F. Fotuhi, N. Modarresi, Z.K. Sadrabad, et al., "Relationship of salivary lactoferrin and lysozyme concentrations with early childhood caries," J. Dent. Res. Dent. Clin. Dent. Prospect., vol. 9, pp.109-114, Spring 2015.

[27] S. Shifa, M.S. Muthu, D. Amarlal, V. Rathna Prabhu, "Quantitative assessment of IgA levels in unstimulated whole saliva of caries-free and caries-active children," J. Indian Soc. Pedod. Prevent. Dent., vol. 26, pp. 158-161, December 2008.

[28] A.V. Amerongen, Alih bahasa: R. Abyono, Ludah dan kelenjar ludah, arti bagi kesehatan gigi, $1^{\text {st }}$ e.d. Yogyakarta: Gadjah Mada University Press, 1991, pp. 19, 43, 49.

[29] S.F. Khan, G. Katti, I. Baba, N. Khan," Age-related changes of salivary IgA among healthy subjects," J. Indian Acad. Oral Med. and Radiol., vol. 27, pp. 203-206, November 2015.

[30] L.J. Brady, D.A. Piacentini, P.J. Crowley, P.C. Oyston, A.S Bleiweis, "Differentiation of salivary agglutinin mediated adherence and aggregation of mutans streptococci by use of monoclonal antibodies against the major surface adhesin P1," Infect. and Immun., vol. 60, pp. 1008-1017, March 1992.

[31] M.L. Lundin, K. Hamberg, D. Ericson, "Salivary IgA reactions to cell surface antigens of oral streptococci," Oral Microbial. and Immunol., vol. 19, pp. 188-195, June 2004.

[32] D.J. Smith, "Dental caries vaccines: prospects and concern," Crit. Rev. Oral Biol. Med., vol. 13, pp. 44 335-349, 2002.

[33] S. Pal, M. Mitra, J. Mishra, S. Saha, B. Bhattacharya," Correlation of total salivary secretory immunoglobulin A (SIgA) and mutans specific SIgA in children having different caries status," J. Indian Soc. Ped. and Prev. Dent., vol. 31, pp. 270274, October-December 2013.

[34] A. Bagherian, G.Asadikaram, "Comparison of some salivary characteristics between children with and without early childhood caries," Indian J. Dent. Res., vol. 23, pp. 628-632, September-October 2012

[35] A. Vasilescu, Q. Wang, M. Li, R. Boukherroub, S. Szunerits, "Aptamer-based electrochemical sensing of lysozyme," Chemo, vol. 4, pp. 1-20, June 2016.

[36] D. Cao, H. Wu, Q. Li, Y. Sun, T. Liu, J. Fei, et al.,' Expression of recombinant human lysozyme in egg whites of transgenic hens," Plos One, vol.10, pp. e0118626, February 2015.

[37] Helal, Biopharmacetutical investigations of the effects of immune-modulatory plant extracts and phytochemicals on lysozyme expression in human cells, Dissertation, Berlin: Freie Universitat Berlin, 2011, pp. 1-10.

[38] C.W.B. Peters, U. Kruse, R. Pollwein, K.H. Grzeschik, A.E. Sippel, "The human lysozyme gene. Sequence organization and chromosomal localization,” Eur. J. Biochem., vol. 182, pp. 507 516, July 1989

[39] T.K. Fábián, P. Hermann, A. Beck, P. Fejérdy, G. Fábián, "Salivary defense proteins: their network and role in innate and acquired oral immunity,” Int. J. Mol. Sci. vol.13, pp. 4295-4320, April 2012.

[40] M.A. Kmiliauskis, P. Palmeira, C. Arslanian, G.N. Pontes, B.T Costa-Carvalho, C.M. Jacob, et al.,"Salivary lysozyme levels in patients with primary immunodeficiencies," Allergol et Immunopathol., vol. 33, pp. 65-68, March-April 2005.

[41] Y.B. Wang, G.R. Germaine, "Effect of lysozyme on glucose fermentation, cytoplasmic $\mathrm{pH}$, and intracellular potassium concentrations in Streptococcus mutans 10449," Infect. and Immun., vol. 59, pp. 638-644, February 1991

[42] M.L. Vidal, J. Gautron, Y. Nys, "Development of an ELISA for quantifying lysozyme in hen egg white," J. Agric. Food Chem. vol. 53, pp. 2379-2385, April 2005.

[43] A. Zalewska, M. Knaś, J. Szulimowska, N. Waszkiewicz, K Wołosik, D. Waszkiel, "Nonspecific immune factors in the whole unstimulated saliva of human infants, children and adolescents,” Dent. Med. Probl., vol. 50, pp. 291-297, 2013.

[44] A.V.N. Amerongen, E.C.I. Veerman, "Saliva-the defender of the oral cavity," Oral Diseases, vol. 8, pp. 12-22, January 2002.

[45] I.E. Svendsen, L. Lindh, T. Arnebrant, "Adsorption behaviour and surfactant elution of cationic salivary proteins at solid/liquid interfaces, studied by in situ ellipsometry," Colloid. and Surf. B. Biointerf., vol. 53, pp. 157-166, December 2006.

[46] T. Hyypp, L. Karhuvaara, J. Tenovuo, M. Lumikari, P. Vilja "Antimicrobial factors in whole saliva of human infants: A longitudinal study," American Academ. Pediatr. Dent., vol. 11, pp. 30-6, March 1989.

[47] P.K. Singh, M.R. Parsek, E.P. Greenberg, "A component of innate immunity prevents bacterial biofilm development," Nature, vol. 417, pp. 552-555, May 2002

[48] J. Bai, Q. Zhou, Z.Y. Bao, X.X. Li, M. Qin, "Comparison of salivary proteins between children with early childhood caries and children without caries," Zhonghua Kou Qiang Yi Xue Za Zhi, vol. 42, pp. 21-23, January 2007.

[49] J. Lertsirivorakul, B. Petsongkram, P. Chaiyarit, S Klaynongsruang, W. Pitiphat, "Salivary lysozyme in relation to dental caries among Thai preschoolers," Pediatr. Dent., vol. 39, pp. 343-347, Summer 2015.

[50] K.R. Felizardo, R.B. Goncalves, W.D. Schwarcz, R.C.P. Frederico, S.M. Maciel, F.B. de Andrade, "An evaluation of the expression profiles of salivary proteins lactoferrin and lysozyme and their association with caries experience and activity," Rev. Odonto. Ciênc., vol. 25, pp. 344-349, 2010

[51] G.F. Hao, H.C. Lin, "Relationship of concentration of lactoferrin and lysozyme in saliva and dental caries in primary dentition," Zhonghua Kou Qieng Yi Xue Za Zhi, vol. 44, pp. 82 84, February 2009

[52] S. Bhalla, S. Tandon, K. Satyamoorthy, "Salivary proteins and early childhood caries: A gel electrophoretic analysis. Contemp," Clin. Dent., vol. 1, pp. 17-22, January- March 2010.

[53] R.D. Nogueira, A.C. Alves, M.H. Napimoga, D.J. Smith, R.O Mattos RO, "Characterization of sIgA responses in children heavily exposed to the oral bacterium S mutans: Influence of specific antigen recognition in infection," Infect. and Immun., vol. 73, pp. 5675-5684, June 2005. 
[54] R.O. Mattos, D.J. Smith, "Vaccination approach to control infections leading to dental caries," J. Braz. Oral Sci., vol. 3, pp. 595-608, 2004.

[55] K. Nakano, R. Nomura, N. Shimizu, I. Nakagawa, S. Hamada, T. Ooshima, "Development of a PCR method for rapid identification of new Streptococcus mutans serotype k strains," J. Clin. Microbiol., vol.42, pp. 4925-4930, November 2004.

[56] N.M Ribeiro, M.A. Ribeiro, "Breastfeeding and early childhood caries: A critical review," J. Pediatr., vol. 80, pp. 199-210, 2004.

[57] Y. Shibata, K. Ozaki, M. Seki, T. Kawato, H. Tanaka, Y. Nakano, Y. Yamashita, "Analysis of loci required for determination of serotype antigenicity in Streptococcus mutans and its clinical utilization," J.Clin. Microbiol., vol. 41, pp. 41074112, September 2003

[58] M. Hirasawa, K. Takada, "A new selective medium for Streptococcus mutans and the distribution of $\mathrm{S}$. mutans and $\mathrm{S}$. sobrinus and their serotypes in dental plaque," Caries Res., vol. 37, pp. 212-217, May-June 2003

[59] R. Nomura, K. Nakano, O. Oshima, "Molecular analysis of the genes involved in the biosynthesis of serotype spesific polysaccharide in the novel serotype k strains of S. mutans,"
J. Oral Microbiol. and Immun., vol. 20, pp. 303-309, October 2005.

[60] M.F. Rizal, B.M. Bachtiar, "Serotype distributions of S mutans in children with caries," IADR SEAADE, September 2007 (abstract).

[61] E. Octiara, S. Budiardjo, M.F. Rizal, E. Bahtiar, "Respons sIgA anti-S. mutans serotipe $\mathrm{f}$ pada anak karies dan bebas karies (Kajian pada anak dengan riwayat minum susu botol)," Dentika Dent. J., vol. 13, pp. 120-125, 2008.

[62] J.W. Jenzano, S.L. Hogan, R.L. Lundblad, "Factors influencing measurement of human salivary lysozyme in lysoplate and turbidimetric assays," J. Clin. Microbiol., vol. 24, pp. 963-967, December 1986.

[63] V.J. Iacono, B.J. Mackay, S. Dirienzo, J.J. Pollock, "Selective antibacterial properties of lysozyme for oral microorganisms,' Infect. and Immun., vol. 29, pp. 623-632, August 1980.

[64] V. Kirstila. P. Hakkinen, H. Jentsch, P. Vilja, J. Tenovuo, "Longitudinal analysis of the association of human salivary antimicrobial agents with caries increment and cariogenic micro-organisms: a two year cohort study," J.Dent. Res., vol 77, pp. 73-80, January 1998. 